\title{
Paleostress Analysis of Atlantic Crustal Extension in the Quebec Appalachians
}

\author{
Stéphane Faure, ${ }^{1}$ Alain Tremblay, ${ }^{2}$ Michel Malo, ${ }^{3}$ and Jacques Angelier ${ }^{4}$ \\ Consortium de Recherche en Exploration Minérale, Université du Québec à Montréal, \\ C.P. 8888 succ. Centre-ville, Montréal, Québec H3C 3P8, Canada \\ (e-mail: faure.stephane@uqam.ca)
}

\begin{abstract}
A B S T R A C T
A paleostress analysis using normal fault slip data and Jurassic dike trends has been conducted in the Quebec and New England Appalachians. Stress tensor analysis of fault slip by a numerical inversion method has distinguished homogeneous and directionally consistent E-W- and NW-SE-oriented extensional stress regimes in the Quebec Appalachians and St. Lawrence Lowlands. The directions of extension compare well with the mean direction of extensional stress inferred from the Jurassic dolerite dike trend in New England. Both extensions are interpreted as the result of rift-related stress associated with the separation of North America and Africa, early in the Late TriassicEarly Jurassic fragmentation of Pangea. The paleostress field configuration is assumed to be related to the direction of divergent plate motion. The N-S and NE-SW Late Proterozoic faults that bordered the Quebec Reentrant and Taconian-Acadian structures of the Quebec Appalachians appear to have played a significant role in the distribution of later stress regimes in the upper part of the lithosphere. The NNE-SSW-trending regional and mesoscopic normal faults in southern Quebec are interpreted as linked to the formation of Mesozoic rift basins in Massachusetts and Connecticut and synchronous with Early and Middle Jurassic dike emplacement in the Quebec and New England Appalachians.
\end{abstract}

\section{Introduction}

Structural and sedimentological features related to the opening of the North Atlantic Ocean are well recorded along the east coast of maritime Canada and the United States. Seismic and marine geology and oil exploration and deep-sea drilling projects have provided essential information concerning the development and evolution of continental crust fragmentation processes that led to the formation of this major ocean. Sedimentary basins and normal

Manuscript received March 21, 2005; accepted December 12, 2005.

${ }^{1}$ Author for correspondence.

${ }^{2}$ Département des Sciences de la Terre et de 1'Atmosphère, Université du Québec à Montréal, C.P. 8888 succ. Centre-ville, Montréal, Québec H3C 3P8, Canada.

${ }^{3}$ Institut National de la Recherche Scientifique-Eau, Terre et Environnement, Centre Géoscientifique de Québec, 880 Chemin Sainte-Foy, C.P. 7500, Québec, Québec G1V 4C7, Canada.

${ }^{4}$ Observatoire Océanologique de Villefranche-sur-Mer, Université Pierre et Marie Curie, Port de la Darse, C.P. 48, 06235 Villefranche-sur-Mer, France. faults related to Late Triassic-Jurassic extension are well-documented offshore. On land however, extensional features are limited to the margin of the northeastern edge of North America (fig. 1). In the Quebec Appalachians, Jurassic extension is recorded by dikes intruded at distances as great as $300 \mathrm{~km}$ west of the continental edge (fig. 1), but no other type of structures have been clearly assigned to this continental extension.

In this article, we address the problem of Atlantic-type rifting through an extensive paleostress analysis of normal faults that are chronologically and mechanically consistent with opening of the North Atlantic Ocean. In the Quebec Appalachians, the presence of such brittle faults and dikes implies that a widespread intraplate deformation occurred in Jurassic time, and these faults and dikes record deformational processes that are otherwise difficult to document. Our results are compared with extension directions deduced from the geometry of rift basins and dike swarms in northeastern North America and with paleostress anal- 


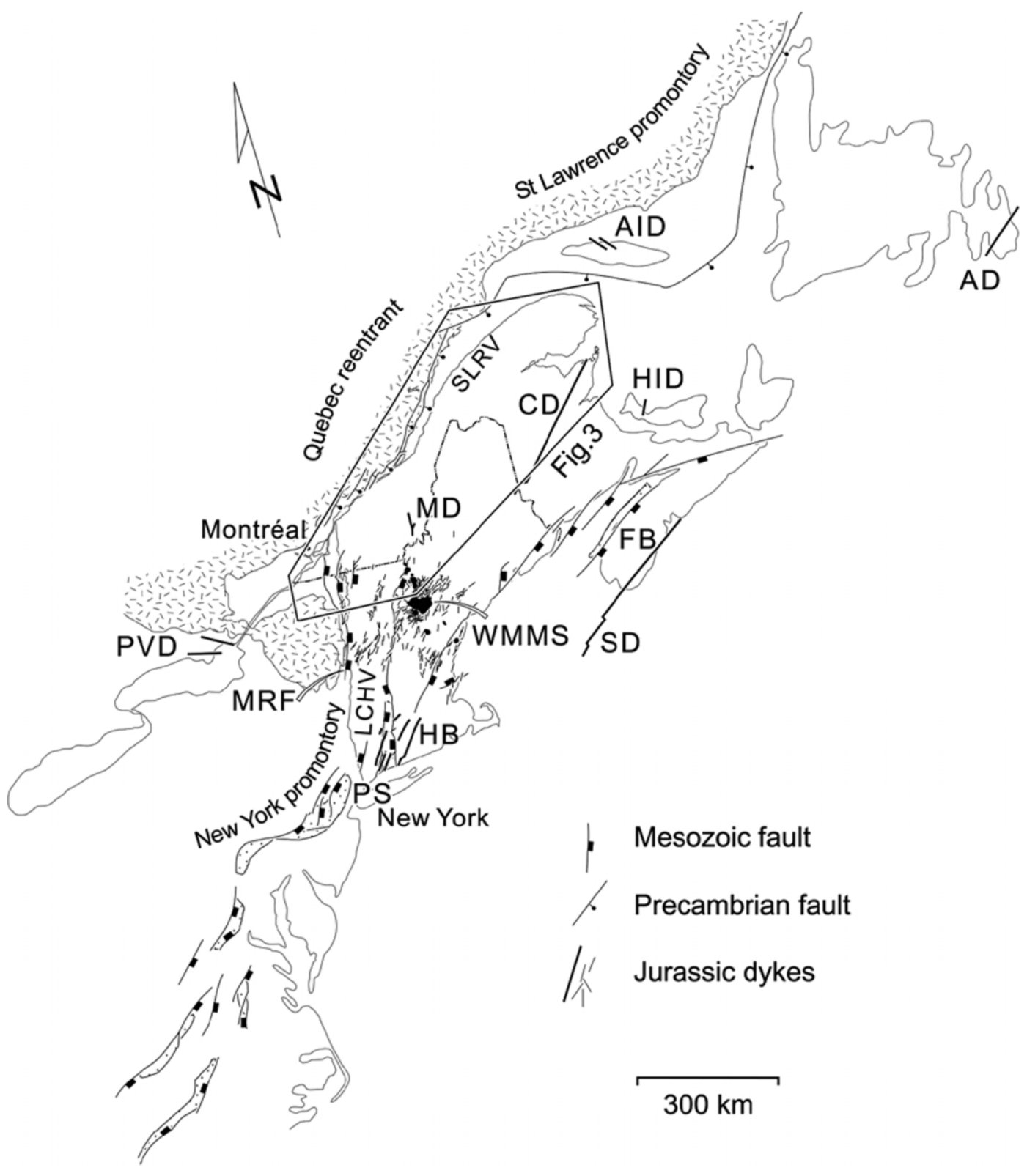

Figure 1. Distribution of Late Triassic-Jurassic plutons, dikes, rift-basins, and faults in the northern Appalachians and adjacent regions (symbols on faults indicate dip directions). Precambrian faults reactivated as normal faults in the Mesozoic. $A I D=$ Anticosti Island dikes, $A D=$ Avalon dike, $C D=$ Caraquet dike, $F B=$ Fundy basin, $H B=$ Hartford basin, $H I D=$ Hog Island dike, $L C H V=$ Lake Champlain-Hudson River valleys, $M D=$ Mégantic dike; $M R F=$ Metawee River Fault, $P V D=$ Picton and Varty Lake dikes, $P S=$ Palisade sills, $S D=$ Shelburne dike, $S L R V=$ St. Lawrence River valley, and WMMS = White Mountain Magma Series.

yses conducted elsewhere in the northern Appalachians.

\section{Regional Geology}

The Quebec Appalachians consist of three principal lithotectonic assemblages: Cambro-Ordovician rocks outcropping in the St. Lawrence Lowlands and the Humber and Dunnage zones (St-Julien and Hubert 1975; Williams 1979|, Upper Ordovician to Devonian rocks of the Gaspé Belt (Bourque et al. 1995), and Carboniferous cover rocks of the Maritime Basin (Bradley 1982). In the northern Appalachians (fig. 1), the present-day location of the 
Quebec Reentrant and the New York and St. Lawrence promontories is interpreted as an inherited geometry of the western margin of early $\mathrm{Pa}$ leozoic Iapetus Ocean (Thomas 1977; Stockmal et al. 1987). In late Precambrian time, rift-related normal faults trending approximately N-S and NE-SW developed along the Laurentian craton, parallel to the Lake Champlain-Hudson River valleys and to the St. Lawrence River valley, respectively. Since that time, these deep-seated structures have played a major role in the tectonic evolution of the Appalachian Belt. Some of these normal faults were reactivated as thrust faults in southern Quebec or as strike-slip faults in Gaspé and are suggested to have served as planes of weakness for the development of major structures related to the MiddleLate Ordovician Taconian (St-Julien et al. 1983; Spencer et al. 1989; Hayman and Kidd 2002; Séjourné et al. 2003) and/or the Middle Devonian Acadian orogenies (Malo and Bourque 1993). After the Acadian Orogeny, the Quebec Appalachians experienced intraplate brittle deformation related to the Laurentia-Gondwana collision (Faure et al. 1996a; Jutras et al. 2003a) during the Alleghanian Orogeny (Early Permian), the youngest tectonic pulse of the Appalachian Orogeny (Williams and Hatcher 1983).

In Mesozoic time, the Appalachian Belt was subjected to an extensional stress regime associated with the Late Triassic-Early Jurassic breakup of Pangea and related tectonism and magmatism (McHone et al. 1987; Manspeizer et al. 1989). The existence of $178 \pm 8$-Ma dikes on Anticosti Island (Wanless and Stevens 1971) and of a $195.5 \pm 1.4$ Ma dike in southern Quebec (Roddick et al. 1992) is the only direct evidence for Jurassic extension in the Quebec Appalachians. The Early-Middle Jurassic White Mountain Magma Series (WMMS) in New Hampshire forms a group of alkaline, intraplate, and nonorogenic plutons that outline an elongated N-S pattern parallel to the Lake Champlain-Hudson River valleys (fig.1; Manspeizer et al. 1989). Cretaceous magmatism belonging to the New England-Quebec Igneous Province occurred in southern Quebec (Monteregian plutons) as well as in Vermont and Maine (dikes), and it represents the youngest tectonomagmatic event (McHone 1978; Foland et al. 1986). At present, the St. Lawrence River and Champlain Lake-Hudson River valleys are among the most seismically active regions in northeastern North America, where neotectonism occurs (Oliver et al. 1970; Barosh 1986; Hasegawa 1991; Lamontagne et al. 2003).

\section{Paleostress Tensor Analysis}

To determine the paleostress orientations of minor fault slip data, the numerical inversion method developed by Angelier (1984, 1989, 1994) was used. Shear sense indicators on minor brittle faults were established based on criteria suggested by Hancock (1985) and Petit (1987). The principle behind this method was first proposed by Carey and Brunier (1974) and was based on the assumptions of Wallace (1951) and Bott (1959) that the direction and sense of shear stress along a fault correspond to a single common stress tensor. The results are expressed in terms of reduced stress tensors that give the attitude of the maximum $(\sigma 1)$, intermediate $(\sigma 2)$, and minimum $(\sigma 3)$ compressional stress axes $\mid \sigma 1>$ $\sigma 2>\sigma 3$, with pressure considered positive) and in terms of the $\Phi$ ratio $(\Phi=[\sigma 2-\sigma 3] /[\sigma 1-\sigma 3])$, which quantifies the variation in principal stress magnitudes. The latter ratio varies from $0(\sigma 2=\sigma 3)$ to 1 $(\sigma 1=\sigma 2)$, which corresponds to prolate (cigarshaped) and oblate (pie-shaped) stress ellipsoids, respectively. The average angle of the largest possible values of computed shear allows determination of the quality of the results for each data set, and the consistency of each fault slip datum with the mean stress tensor is checked using individual misfit. For a discussion of the calculation methods and their accuracy, see Etchecopar et al. (1981), Angelier (1984, 1989, 1990, 1994), Guiraud et al. (1989), Dupin et al. (1993), Gapais et al. (2000), and Yamaji (2003).

In most cases, fault populations at single observation sites correspond to a number of distinct stress regimes. Reliable determination of paleostress regimes frequently requires the separation of fault slip data into subsets that can be attributed to distinct tectonic events. The recognition of polyphase faulting is supported by crosscutting relationships between different generations of structures (faults, veins, folds, and dikes) and by superimposed sets of slickenside lineations indicating successive slips on fault planes. Polyphase tectonism commonly results in apparently large misfits. In sites where such inhomogeneous data sets are found, computed separations of stress tensors and related subsets of fault slip data were performed following a procedure proposed by Angelier and Manoussis (1980) and discussed by Angelier (1984).

Qualitative determination of $\sigma 3$ axes from dike trends yields complementary information for characterizing the paleostress directions. Extensional axes deduced from faults and dikes were compiled to reconstruct a paleostress map. Smoothed $\sigma 3$ 


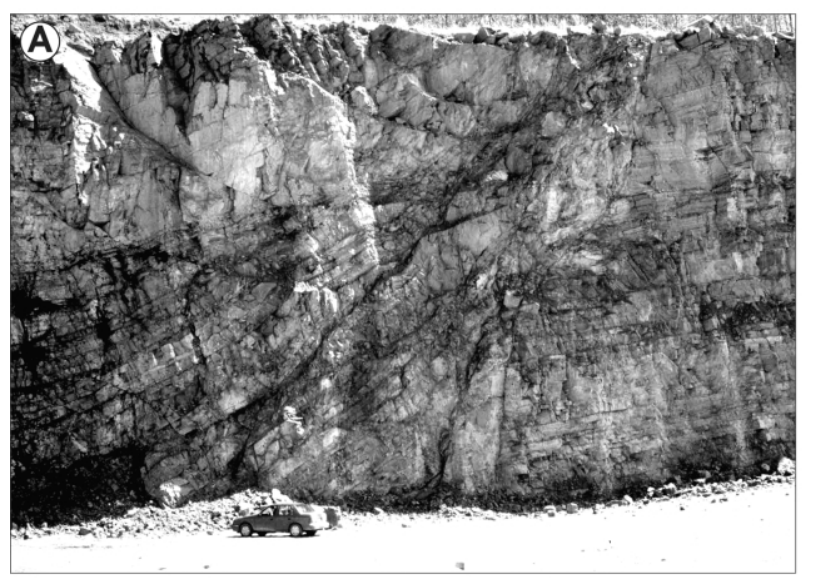

East

West
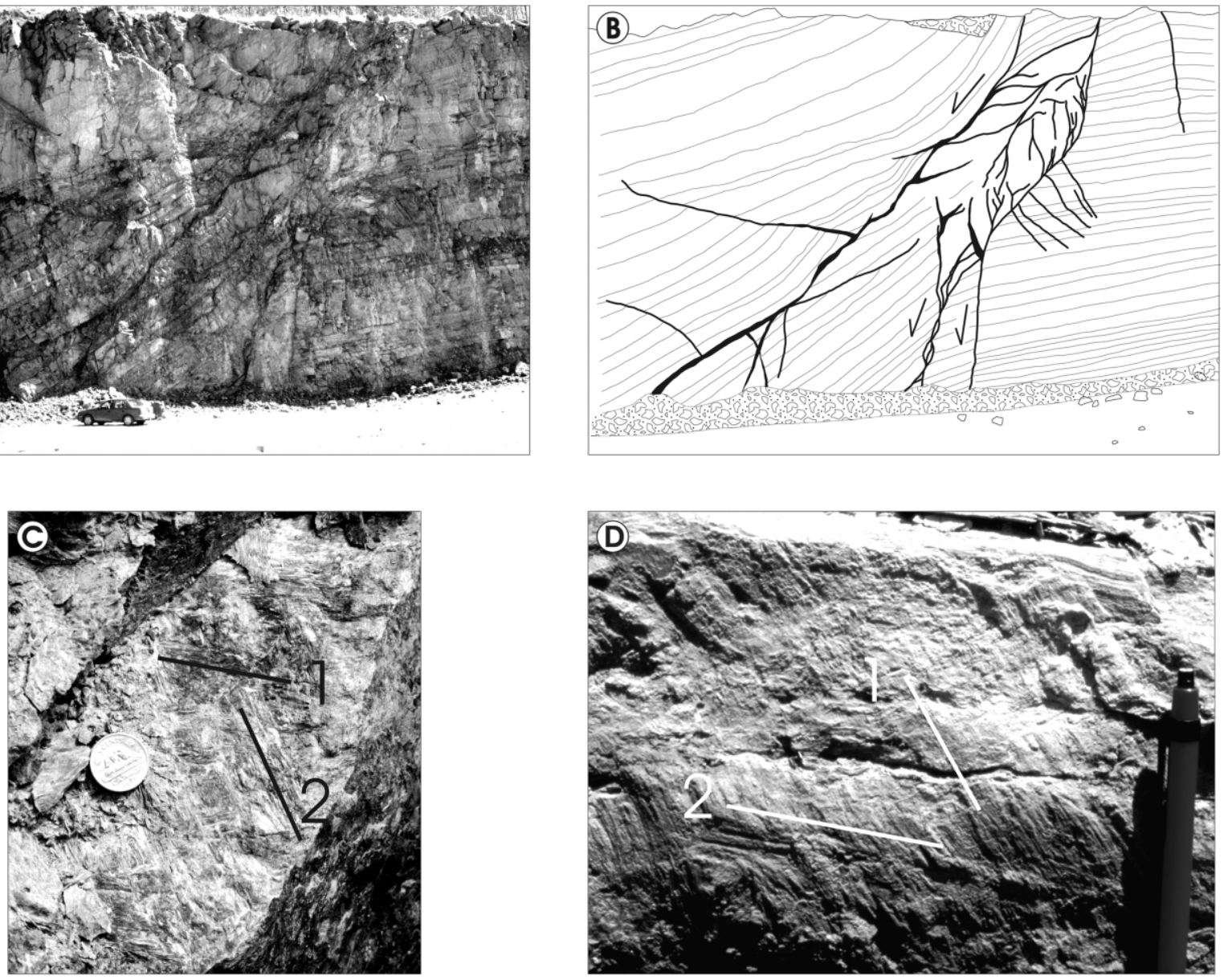

Figure 2. $A$, Complex neoformed normal fault in Ordovician limestones of the St. Lawrence Lowlands with $B$, kinematic interpretation (site 49 in fig. 3; Saint-Isidore Station). Faults are marked by black lines, and bedding is marked by thin gray lines. $C$, Site 58 is an example in which a fault in Middle Devonian conglomerates acted first as a strike-slip fault (line 1) during the Alleghanian compression but was reactivated as a normal fault (line 2) during the NW-SE extension. $D$, Site 128 is an example where a normal slip fault (line 1) associated to the NW-SE extension has been reactivated as a strike-slip fault (line 2) during Late Cretaceous-Early Tertiary ENE-WSW directed compression (Faure et al. 1996b).

stress trajectories were then determined using a computed distance-weighting method that takes into account the effect of local stress deviations of the regional stress field (Lee and Angelier 1994).

Description of Faults and Paleostress Reconstruction. We distinguish two categories of brittle faults: neoformed and inherited. Neoformed faults did not exist before the tectonic event. They usually offset the most competent lithologies. Fault slip data sets of this category are geometrically simple, with conjugated planes and coaxial intersections. However, normal faulting in the St. Lawrence Lowlands may present a more complex geometry (fig. $2 A, 2 B$ ). Neoformed faults are filled with milky quartz (in sandstones) or carbonate minerals (in limestones), with minor amounts of chlorite and/or white mica. Fault planes commonly are thin and planar and show well-developed slickenside fibers and accretion steps. Inherited faults refer to reactivated planes of weakness, such as preexisting faults, veins, joints, or cleavages. They are the dominant category of faults in the Quebec Appalachians. Such faults commonly exhibit irregular surfaces and are sealed by quartz, calcite, iron carbonates, phyllosilicates, and oxide minerals. Crosscutting or overprinting relationships between different generations of striae on single fault surfaces are common. 


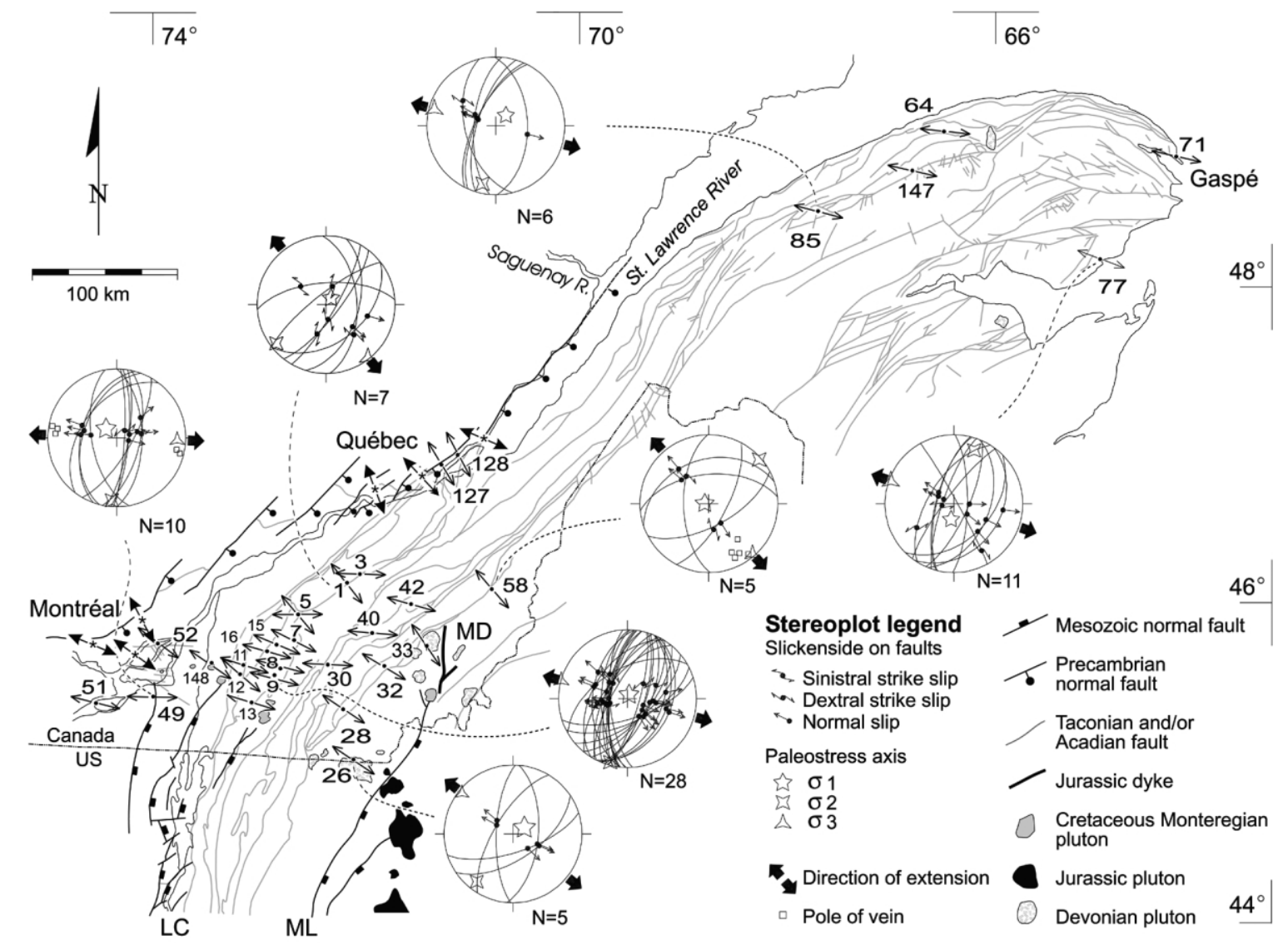

Figure 3. Calculated $\sigma 3$ paleostress axis orientations with corresponding site numbers in the Quebec Appalachians and the St. Lawrence Lowlands. Typical fault slip data sets are shown as examples in stereoplots, with the complete stress axes orientations calculated in three dimensions; fault planes are shown as thin lines, and slickensides are indicated by black dots with arrows (divergent for normal slip; double arrows for normal-oblique slip). Open squares are represent vein and joint sets. Taconian and Acadian faults are shown as gray lines. $M D=$ Mégantic dike, $M L=$ Monroe Line, $L C=$ Lake Champlain. Paleostress axis with solid arrowheads and stars from Rocher and Tremblay (2001) and Rocher et al. (2003). Normal faults from Clark (1972), Charbonneau (1980), and Colpron (1990).

The inversion of tectonic data through a computer-based method was applied to striated normal faults occurring in quarries, road cuts, and natural outcrops of the Quebec Appalachians and the St. Lawrence Lowlands (Faure 1995). Site locations, reference numbers, the direction of $\sigma 3$ axes, and representative stereoplots are shown in fig. 3. Table 1 summarizes, for each site, the most important parameters in these determinations: the number of striated faults used to compute the stress tensor, the orientation and dip of principal axes $\sigma 3$ and $\sigma 1$, the $\Phi$ values, and the average angles estimator (Ang.). Most sites are located in southern Quebec (fig. 3). This geographic distribution is mainly controlled by the quality and density of outcrops and ease of road access; it does not reflect the real extent of faulting. In 30 sites, we reconstruct
31 stress tensors (site 5 has two tensors) that correspond to a coherent and broad regional ESE-WNW extension. Of the 30 sites, 19 display only one set of normal faults that are attributed to ESE-WNW extension. The 11 remaining sites show two or three subsets of normal faults, corresponding to two distinct extensional events. One of these events is correlated with the regional ESE-WNW extension discussed here, whereas the other is attributed to Cretaceous N-S extensional tectonics in southern Quebec. The relative chronology of these two events is discussed below and in more detail by Faure et al. (1996b). Fault populations are characterized by conjugate sets of normal faults forming horst and graben structures. At several sites, a network of subvertical extensional veins and joints is found in close association with normal 
Table 1. Results of Paleostress Determinations Using Fault Slip Data Sets in the Quebec Reentrant

\begin{tabular}{|c|c|c|c|c|c|c|c|}
\hline Site & No. & $\sigma 3$ & $\sigma 1$ & Ratio $\Phi$ & Ang. & Lat. $(\mathrm{N})$ & Long. (W) \\
\hline 1 & 7 & 14203 & 03680 & .55 & 15 & $46^{\circ} 08^{\prime}$ & $71^{\circ} 58^{\prime}$ \\
\hline 3 & 7 & 27117 & 08473 & .64 & 10 & $46^{\circ} 11^{\prime}$ & $71^{\circ} 52^{\prime}$ \\
\hline 5 & 21 & 27000 & 18088 & .55 & 14 & $45^{\circ} 55^{\prime}$ & $72^{\circ} 23^{\prime}$ \\
\hline 5 & 8 & 32002 & 20485 & .70 & 12 & $45^{\circ} 55^{\prime}$ & $72^{\circ} 23^{\prime}$ \\
\hline 7 & 5 & 11701 & 02082 & .24 & 16 & $45^{\circ} 45^{\prime}$ & $72^{\circ} 25^{\prime}$ \\
\hline 8 & 5 & 28517 & 16460 & .31 & 6 & $45^{\circ} 49^{\prime}$ & $72^{\circ} 32^{\prime}$ \\
\hline 9 & 28 & 28500 & 02085 & .38 & 11 & $45^{\circ} 32^{\prime}$ & $72^{\circ} 35^{\prime}$ \\
\hline 11 & 5 & 28803 & 09787 & .50 & 6 & $45^{\circ} 35^{\prime}$ & $72^{\circ} 52^{\prime}$ \\
\hline 12 & 5 & 31112 & 09976 & .26 & 2 & $45^{\circ} 32^{\prime}$ & $72^{\circ} 55^{\prime}$ \\
\hline 13 & 14 & 10710 & 23272 & .51 & 12 & $45^{\circ} 21^{\prime}$ & $72^{\circ} 47^{\prime}$ \\
\hline 15 & 6 & 11307 & 35874 & .43 & 15 & $45^{\circ} 43^{\prime}$ & $72^{\circ} 32^{\prime}$ \\
\hline 16 & 19 & 28601 & 02280 & .55 & 11 & $45^{\circ} 41^{\prime}$ & $72^{\circ} 40^{\prime}$ \\
\hline 26 & 5 & 30002 & 03979 & .25 & 8 & $45^{\circ} 02^{\prime}$ & $71^{\circ} 50^{\prime}$ \\
\hline 28 & 4 & 12407 & 22865 & .35 & 7 & $45^{\circ} 20^{\prime}$ & $71^{\circ} 57^{\prime}$ \\
\hline 30 & 4 & 09308 & 32377 & .43 & 7 & $45^{\circ} 37^{\prime}$ & $72^{\circ} 07^{\prime}$ \\
\hline 32 & 6 & 30109 & 17576 & .33 & 11 & $45^{\circ} 38^{\prime}$ & $71^{\circ} 37^{\prime}$ \\
\hline 33 & 4 & 32600 & 05778 & .54 & 14 & $45^{\circ} 45^{\prime}$ & $71^{\circ} 13^{\prime}$ \\
\hline 40 & 4 & 10512 & 24073 & .51 & 3 & $45^{\circ} 50^{\prime}$ & $71^{\circ} 42^{\prime}$ \\
\hline 42 & 5 & 10905 & 25984 & .34 & 6 & $45^{\circ} 59^{\prime}$ & $71^{\circ} 23^{\prime}$ \\
\hline 49 & 10 & 09213 & 31073 & .36 & 6 & $45^{\circ} 21^{\prime}$ & $73^{\circ} 39^{\prime}$ \\
\hline 51 & 8 & 10401 & 35288 & .38 & 11 & $45^{\circ} 17^{\prime}$ & $74^{\circ} 11^{\prime}$ \\
\hline 52 & 4 & 12715 & 29875 & .35 & 3 & $45^{\circ} 41^{\prime}$ & $73^{\circ} 37^{\prime}$ \\
\hline 58 & 5 & 13904 & 27585 & .47 & 3 & $46^{\circ} 07^{\prime}$ & $70^{\circ} 40^{\prime}$ \\
\hline 64 & 4 & 09612 & 21666 & .81 & 24 & $49^{\circ} 01^{\prime}$ & $66^{\circ} 23^{\prime}$ \\
\hline 71 & 4 & 10604 & 00471 & .66 & 6 & $48^{\circ} 47^{\prime}$ & $64^{\circ} 12^{\prime}$ \\
\hline 77 & 11 & 29003 & 19071 & .59 & 15 & $48^{\circ} 12^{\prime}$ & $64^{\circ} 56^{\prime}$ \\
\hline 85 & 6 & 28508 & 04473 & .58 & 5 & $48^{\circ} 32^{\prime}$ & $67^{\circ} 33^{\prime}$ \\
\hline 127 & 11 & 32903 & 07983 & .41 & 10 & $46^{\circ} 53^{\prime}$ & $71^{\circ} 08^{\prime}$ \\
\hline 128 & 7 & 33205 & 07670 & .44 & 10 & $46^{\circ} 58^{\prime}$ & $71^{\circ} 02^{\prime}$ \\
\hline 147 & 5 & 09602 & 20785 & .42 & 11 & $48^{\circ} 50^{\prime}$ & $66^{\circ} 33^{\prime}$ \\
\hline 148 & 5 & 30512 & 09076 & .29 & 2 & $45^{\circ} 35^{\prime}$ & $73^{\circ} 10^{\prime}$ \\
\hline
\end{tabular}

Note. $\quad$ Site $=$ site number, No. $=$ number of faults per site. The $\sigma 3$ and $\sigma 1$ are azimuth and dip of minimum and maximum compressional stress axes, respectively. Ratio $\Phi=(\sigma 2-\sigma 3) /(\sigma 1-\sigma 3)$. Ang. = Average angles of the largest possible values of computed shear.

faulting (fig. 3). Most mesoscopic faults trend NNESSW and dip between $50^{\circ}$ and $70^{\circ}$ (fig. $4 A, 4 B$ ). Dips of reactivated faults are more variable $\left(30^{\circ}-80^{\circ}\right)$. Most slickenside lineations are nearly normal dipslip, with pitch values varying from $70^{\circ}$ to $90^{\circ}$ (fig. $4 C, 4 D)$, although a few slickensides on E-W trending faults show shallower dips that indicate a significant strike-slip component. In the Gaspé Peninsula (fig. 3), numerous mesoscopic normal faults are parallel to N-S-oriented secondary structures (i.e., Riedel-type structures) that are related to older Acadian dextral strike-slip faults (Kirkwood and Malo 1993; Malo and Bourque 1993).

The orientation of calculated $\sigma 3$ axes at all sites varies from E-W to NNW-SSE (figs. 3, 4F; table 1). Most $\sigma 3$ axes are nearly perpendicular to major Taconian and Acadian faults, except at some sites on the Gaspé Peninsula where $\sigma 3$ axes are oblique or subparallel to major E-W-trending structures. Most E-W- to ESE-WNW-oriented $\sigma 3$ axes are found in the Montreal and Gaspé area, whereas SE-NWtrending $\sigma 3$ axes are mainly found in southeastern Quebec (fig. 3). The average plunge dip of $\sigma 3$ axes is nearly horizontal, varying from $0^{\circ}$ to $17^{\circ}$, with a mean value of $6^{\circ}$ (fig. $4 F$; table 1 ). Calculated $\sigma 1$ axes are nearly vertical (plunges being generally steeper than $70^{\circ}$; see fig. $4 F$, table 1 ), which is consistent with pure extensional stress regimes. The $\Phi$ ratios vary between 0.2 and 0.8 , with an average value of 0.46 (table 1). Such $\Phi$ values indicate that the majority of stress ellipsoids are triaxial $(\Phi$ being close to 0.5 ) and that good confidence can thus be given to the orientation of $\sigma 1$ and $\sigma 3$ stress axes. Regional $\sigma 3$ trajectories determined from striated faults are shown on fig. 5 (dashed lines).

Paleostress Determined from Dike Trends. Dike swarms commonly cover large areas, and their average trend is almost perpendicular to the least compressive principal stress direction $(\sigma 3)$ at the time of intrusion (Anderson 1942; Pollard 1987). The state of stress in the crust is mainly controlled by lithospheric-scale deformation and/or deepseated structures, but in the upper crust, it can be locally disturbed by preexisting anisotropy (Emerman and Marrett 1990). In order to compare the normal faulting event considered here with the Ju- 


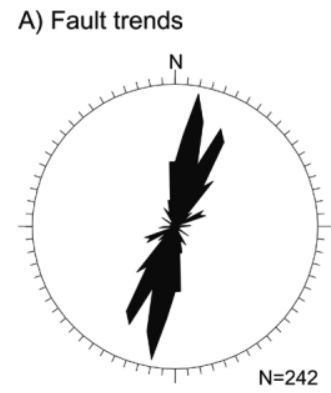

B) Fault dips

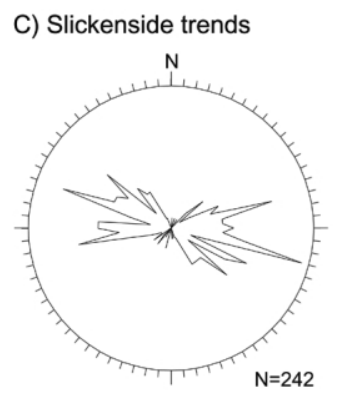

E) Dyke trends

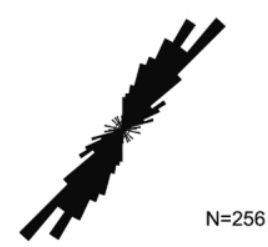

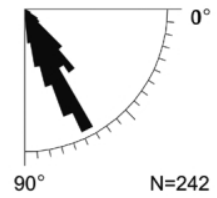

D) Pitchs

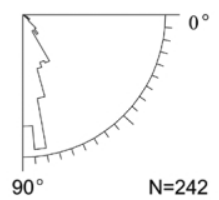

F) Sigma 1 and 3 axis

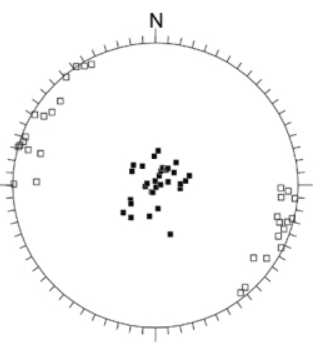

Figure 4. Rose diagrams of striated normal faults and stereogram of the reconstructed paleostress axis related to Mesozoic extension in the Quebec Appalachians. A, Fault trends and $B$, dips of fault planes; $C$, slickenside trends; $D$, pitches of slickenside lineations; $E$, trend of Jurassic dikes in New England and southern Quebec; F, lower hemisphere equal-area plot of paleostress axes. Open squares $=$ least compressive stress component $(\sigma 3)$; solid squares $=$ maximum compressive stress component $(\sigma 1)$.

rassic magmatic event, we have determined the paleostress field using trends of Late Triassic-Jurassic dikes in New England and southern Quebec, which are statistically consistent (figs. 4E, 5). Trajectories of $\sigma 3$ axes deduced from dike orientations suggest a SE-NW extension and are fairly consistent with $\sigma 3$ trajectories calculated from our fault slip stress analysis (fig. 5). The main branch of the N-S-trending Mégantic dike in southern Quebec is consistent with the regional E-W extensional stress axes, whereas the NE-SW branch is more compatible with a local and adjacent NW-SE extension (fig. 3). In the WMMS, the clockwise deviation of $\sigma 3$ axes

area may be attributed to a local deviatoric stress state induced by the plutons themselves or to a NESW oriented fault zone in the basement which could have controlled the emplacement of dikes along such trend (fig. 5).

\section{Discussion}

Timing of Extension. The age of normal faulting is difficult to determine precisely in the Quebec Appalachians because the diagnostic structures occur in rocks that vary in age from late Cambrian to early Carboniferous. However, the relative chronology of the faulting can be established from faults that show crosscutting slickenside lineations. Normal slip motions are observed on several fault surfaces that developed as reverse or strike-slip faults under earlier compressional stress regimes. At 13 sites specifically, preexisting reverse or strike-slip faults developed during the Taconian, Acadian, or Alleghanian Orogenies (Faure et al. 1996a; Faure et al. 2004) have been reactivated as normal faults. Site 58 is an example in which a fault developed in Middle Devonian conglomerates was active first as a strike-slip fault and was reactivated later as a normal fault (figs. $2 C, 3$ ). The initial movement of that structure is mechanically consistent with the $\mathrm{N}-\mathrm{S}$ compression related to the distal expression of the Alleghanian Orogeny in the Quebec Appalachians (Faure et al. 1996a). The normal movement is mechanically compatible with the NW-SE extension, indicating a lower age limit of post-Late Permian for the extensional event. The upper age limit of extension is well constrained at site 128, where a normal slip fault correlated to the NW-SE extension has been reactivated as a strike-slip fault (fig. 2D). The late movement on that fault is mechanically consistent with the ENE-WSW-directed compression that occurred in northeastern North America after the Late Cretaceous-Early Tertiary (Faure et al. 1996b). The upper age limit for these normal faults is also defined by the N-S extension inferred from striated fault planes and the trend of Cretaceous Monteregian plutons and dike swarms (fig. 3; McHone 1988; Faure et al. 1996b). The E$\mathrm{W}$-trending faults in the Montreal area are attributed to Cretaceous magmatism and crosscut the $\mathrm{N}$-S-trending normal faults of the St. Lawrence Lowlands (Clark 1972; Rocher et al. 2003). Such timing correlates with the breakup of Pangea and the opening of the Atlantic Ocean. The same relative chronology between the Appalachian compressional brittle faults and the Triassic-Jurassic extensional brittle faults has been also observed in the Quebec city area (Rocher and Tremblay 2001). 


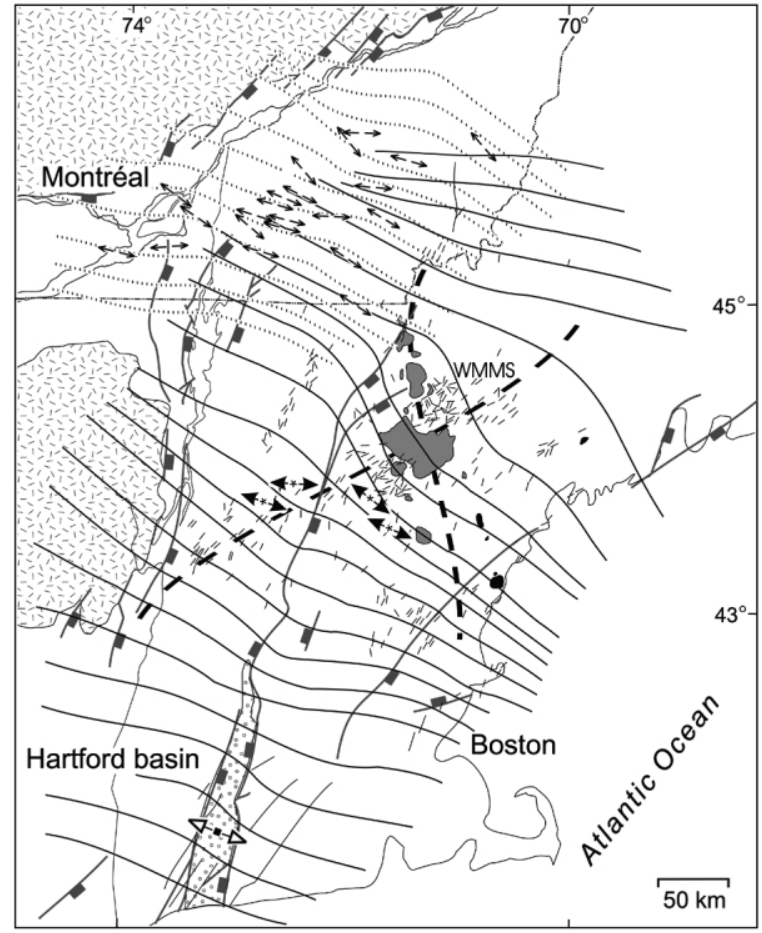

Figure 5. Paleostress trajectories of $\sigma 3$ axes constructed from striated fault slip data (dashed lines) in southern Quebec and from dike trends (black lines) in New England. Neoformed or reactivated normal faults of Jurassic age are shown as gray lines. Possible deep-seated basement faults are shown as heavy dashed lines. Dike trends from McHone (1984). Other paleostress axes from Hardcastle (1989) and Hardcastle and Albaugh (1990) are displayed as asterisks with solid arrowheads. Mean paleostress axis in the Hartford Basin (square with open arrows) from de Boer (1992). WMMS = White Mountain Magma Series. Plutons in black belong to the coastal New England plutonic suite.

Finally, it should be noted that at all sites, the orientation of calculated $\sigma 1$ axes is close to vertical, while that of $\sigma 2$ and $\sigma 3$ is horizontal (see table 1). This suggests that the stress tensors have not been disturbed or rotated by any subsequent tilting and indirectly supports the late age of extensional deformation proposed here.

However, the relative chronology between the E$\mathrm{W}$ and the NW-SE extensions is not well constrained. We observed crosscutting relationships between the different generations of normal slickenside lineations only at site 5, which indicates that the E-W extension occurred before the SE-NW extension.

In the Quebec Appalachians, the existence of Jurassic dikes can also be used to constrain the age of the extensional stress regime that we have documented with fault slip data. In southern Quebec, the Mégantic diabase dike cropping out to the northeast of the Cretaceous Mont Mégantic (figs. $1,3)$ yielded an age of $195.5 \pm 1.4 \mathrm{Ma}\left({ }^{40} \mathrm{Ar} /{ }^{39} \mathrm{Ar}\right.$ on biotite; Roddick et al. 1992). The dike is vertical and is expressed as a prominent N-S magnetic anomaly of $>50 \mathrm{~km}$ in length (Geological Survey of Canada 1985a, 1985b; aeromagnetic maps C21066G, C21067G) that crosscuts the Acadian structural trend. The trend of this dike suggests that its emplacement was controlled either by EW-oriented extension or by a deep-seated N-Strending weakness zone.

Two $178 \pm 8$-Ma quartz-tholeiite dikes crop out on Anticosti Island in the Gulf of St. Lawrence (fig. 1; Wanless and Stevens 1971; Bédard 1992). These dikes strike parallel to a NW-SE-oriented set of post-Taconian normal faults (Petryk 1981; Bertrand 1987). In southern Ontario, two dikes trending ESEWNW (labeled PVD in fig. 1) yielded ages of 170 and $173 \mathrm{Ma}$ (K-Ar on phlogopite; Barnett et al. 1984). Their emplacement has been attributed to reactivated Proterozoic basement faults (Barnett et al. 1984). In central New England, plutons belonging to the WMMS (figs. 1,5) yielded radiometric ages ranging from 200 to $155 \mathrm{Ma}$ (Foland and Faul 1977). Their broad trend is NNW-SSE, parallel to the Champlain Lake-Hudson River and Connecticut River valleys and along strike with Devonian and Cretaceous plutons to the north, thus emphasizing the hypothesis of a genetic link between pluton emplacement and an inherited deep-seated NNW-SSE-oriented basement zone of weakness (figs. 3, 5). Evidence for SE-NW extension has been found in a 158-Ma granite from the WMMS (figs. 1, 5; Hardcastle and Albaugh 1990), suggesting that the extensional regime was active until Late Jurassic time.

Correlation with Jurassic Basins, Dikes, and Regional Faults. Regional correlations between calculated paleostress axes and the youngest structures of the northern Appalachians provide a basis of comparison for our results. Considered with caution, the orientation and distribution of Late Triassic-Early Jurassic rift basins and dikes give an approximation of the mean direction of extension that prevailed during that time. The comparison between stress tensors determined in this article and other stress studies in the northern Appalachians is consistent with the interpretation that the E-W and ESE-WNW extensions found in the Quebec Appalachians are an intraplate and far-field manifestation of opening of the North Atlantic Ocean.

Triassic-Jurassic rift basins are distributed along 
the eastern edge of the Appalachian Belt along a NE-SW orientation with one right-stepping offset (fig. 1). Most of these rift basins represent halfgrabens that are bounded by listric normal faults and were formed where the extension direction was at a high angle to preexisting structures (Manspeizer et al. 1989; Withjack et al. 1998). Preexisting faults that were oblique to the extension direction show a significant component of strike-slip motion (Schlische 1993, 2003). A dominant ESE-WNW extension is commonly inferred for the formation of these basins (McMaster et al. 1980; Manspeizer and Cousminer 1988). In Quebec, high-resolution marine seismic reflection data acquired in the St. Lawrence River (NE of Saguenay River) suggest that the St. Lawrence rift system, with $>700 \mathrm{~m}$ of basement topographic relief, varies from a half-graben to a graben structure from SW to NE (Tremblay et al. 2003). On land, the St-Laurent Fault, which is part of this rift system, shows an apparent normal displacement with an estimated vertical throw of ca. $2 \mathrm{~km}$ (fig. 3; Rondot 1989). Structural analysis (Lemieux et al. 2003) and isotopic characterization (C, O, Sr, and $\mathrm{Pb}$; Carignan et al. 1997) of this major crustal fault suggest that rift structures are younger than the Devonian Charlevoix impact cratering event (Rondot 1968). In southern Quebec, N-S- to NE-SW-oriented normal faults (figs. 1, 5) have been mapped in the St. Lawrence Lowlands by Clark (1972) and in the Humber Zone by Charbonneau (1980) and Colpron (1990) and were assigned to a post-Taconian deformation event. These faults are up to $10 \mathrm{~km}$ long, and their apparent vertical displacements have been estimated to be approximately $500-800 \mathrm{~m}$. Their orientations and dip are similar to those of the mesoscopic normal faults used for paleostress determination in this article. These regional-scale normal faults connect to the Champlain Lake and Hudson River valleys fault systems. South of Lake Champlain, for instance, the Metawee River fault is a late normal structure that truncates thrusts of the Taconian orogen (fig. 1; Hayman and Kidd 2002). All of these faults are located $<300 \mathrm{~km}$ north of the Jurassic Hartford Basin and could represent the northward extension of the Newark and Connecticut Valley rift-related fault systems (fig. 1). A similar interpretation was proposed by Hatch (1988) for the Mesozoic reactivation of the Acadian Monroe Line in eastern Vermont and western New Hampshire (fig. 3).

NE-SW-trending, Late Triassic to Early Jurassic dikes are common along the east coast of Newfoundland, maritime Canada, and New England (fig. 1; de Boer et al. 1988; Pe-Piper et al. 1992; Dunn et al. 1998; Pe-Piper and Reynolds 2000). They are longer and wider than the ones found in Quebec or central New England and are believed to be parallel to the rift that separated America from Africa and led to the opening of the North Atlantic Ocean (McHone 1988).

Other Paleostress Tensor Analyses. In the St. Lawrence Lowlands (Montreal and Quebec areas), reconstructed paleostress axes using the inversion of fault slip data and microstructural study of calcite mechanical twinning indicate a NW-SE extension with a major collapse event during the Mesozoic (fig. 3; Rocher and Tremblay 2001; Rocher et al. 2003). In the U.S. Appalachians, quantitative studies using striated faults were used to determine the orientation of paleostress axes related to the opening of the North Atlantic Ocean (Wise 1988; Hardcastle 1989; Hardcastle and Albaugh 1990; de Boer 1992). In central New England, Hardcastle (1989) and Hardcastle and Albaugh (1990) found two sets of normal faults, and the computed paleostress axes suggest both E-Wand SE-NW-oriented extension. The paleostress configurations and related faults are attributed to thermal doming and/or crustal attenuation associated to the opening of the Atlantic Ocean. Similar extensional directions have been found in Jurassic rift basins of southern New England (Wise 1988) and Nova Scotia (de Boer 1992). Paleostress studies from the Hartford and Fundy basins (fig. 1) and the inferred directions of $\sigma 3$ axes point to ESE-WNW and SE-NW extensions, respectively (Wise 1988; de Boer 1992). Jutras et al. (2003b) also note a regular system of NNE-SSW tensile fractures throughout the southern Gaspé Peninsula. They correlate these structures to the TriassicJurassic extension.

Tectonic Interpretation. Two hypotheses can be considered in order to explain the widespread E-Wand SE-NW-oriented extensional paleostress trends identified in Quebec, New England, and maritime Canada.

Hypothesis 1: Stress Partitioning during a Single Phase of Extension. The initial geometry of the Appalachian Belt partly influenced the direction of extensional forces. In southern Quebec, the orientation of preexisting N-S structures in the Champlain Lake valley and NE-SW structures of the St. Lawrence River Rift system may have influenced the configuration of the younger stress regime. Many of the striated faults analyzed in this study display similar orientations to Taconian and Acadian faults, and most calculated $\sigma 3$ axes are nearly perpendicular to Paleozoic structures (figs. 3, 5). Consequently, the E-W and SE-NW extensions could have been contemporaneous, and the distri- 
bution of our computed paleostress tensors may represent the regional partitioning of a broadly ESEWNW-oriented extension that was locally influenced by earlier fault networks. The lack of common crosscutting striae with normal sense of movement on brittle faults (except at site 5) may be an indirect observation in favor of a single and common broad extensional stress vector.

Hypothesis 2: Two Successive Extensional Events. Jurassic stress axes were mainly controlled by the relative plate motions between America and Africa and represent, at least to a first approximation, true directions of extension. According to Klitgord and Schouten (1986), Klitgord et al. (1988), and Beck and Housen (2003), the rifting related to the opening of the Atlantic Ocean occurred in two phases. Early rifting (Late Triassic) is characterized by E-W-directed plate motion and by the formation of major rift basins in the Bay of Fundy and South Georgia, with which the coastal New England plutonic suite is believed to be synchronous (fig. 5; McHone and Butler 1984; Manspeizer et al. 1989). During subsequent rifting (Early Jurassic), the crustal extension axis rotated to an ESE-WNW direction due to the fact that the central Atlantic rift system became linked to the Ligurian Tethys rift (Klitgord et al. 1988). In southern Quebec, the E-W and NW-SE paleostress axes can be interpreted as representing these two phases of extension.

These two hypotheses are, however, complementary. As proposed by several authors (Le Pichon et al. 1977; Swanson 1986; Manspeizer and Cousminer 1988; McHone and Shake 1992; Schlische 2003), regional irregularities of the Paleozoic margin of North America (promontories and reentrants) probably correspond to major zones of weakness that shaped the Triassic-Jurassic continental fragmentation. Late Precambrian normal faults, as well as Taconian, Acadian, and Alleghanian fault zones of the Quebec Appalachians, thus formed potential failure zones that could have been selectively and preferentially reactivated during the opening of the Atlantic Ocean (Kumarapeli 1985; Hasegawa 1986). Such planes of weakness certainly played a significant role in determining the magnitude and style of the subsequent crustal extension.

We suggest that the regional normal faults in southern Quebec (shown on figs. 3, 5) represent the northward continuation of faults bounding the Jurassic Hartford Basin in Massachusetts and Connecticut. Brittle deformation in the northwestern part of the Atlantic rift system (Quebec Appalachians) was mostly localized in the upper part of the crust, where small faults individually account for little extension, although cumulative extension may be appreciable, considering the abundance of the faults. The magmatic activity as well as the rate of subsidence related to this event in the study area can be considered negligible. Jurassic dikes located in the westernmost part of the North Atlantic rift system (Anticosti and southern Ontario dikes) represent fairly small intrusive volumes. Their trends are scattered, and their orientations are mechanically inconsistent with the regional minimum stress field reconstructed here. These dikes occur far into the continental interior, and their emplacement was probably mostly controlled by local planes of weakness. The absence of rift basins in central New England and Quebec probably points to a higher topographic elevation induced by thermal arching of the WMMS plutons in Early Jurassic time. Preliminary results of the apatite fission-track dating of Grenvillian basement rocks near Quebec city argue in favor of active tectonism and anomalous heat flow in Late Jurassic to Early Cretaceous times (Glasmacher et al. 1998, 2002).

In contrast, the southeastern part of the North Atlantic rift system experienced a higher rate of extension and subsidence. Faults were rooted in the lower part of the crust, and magmatic activity and rift basin formation were predominant (Manspeizer et al. 1989). Most associated dikes represent large volumes of magma. They are rectilinear, consistent in trend, and were emplaced along deep-seated crustal structures. Their geometry is believed to reflect that of the regional extensional stress field.

\section{Conclusion}

In the Quebec Appalachians and St. Lawrence Lowlands, Mesozoic tectonism related to the formation of the North Atlantic Ocean was previously inferred from magmatic, thermal, and isotopic studies. The brittle faults and related paleostress reconstruction presented herein are the first structural evidence in favor of a widespread and extended Jurassic extension as far as $400 \mathrm{~km}$ into the interior of the northeastern North American plate. The E-W and SE-NW extensional tectonics are documented by brittle normal faults that are interpreted to have resulted from a rift-related stress regime associated with the separation of North America and Africa during an early stage of the Late Triassic-Jurassic fragmentation of Pangea. The paleostress field configuration is believed to reflect the direction of divergent plate motion, although it is recognized that preexisting Late Pro- 
terozoic normal faults and Taconian, Acadian, and Alleghanian structures played a significant role. These brittle faults are interpreted as kinematically linked to regional faults bounding Mesozoic rift basins in Massachusetts and Connecticut and are considered to be synchronous with the emplacement of Early and Middle Jurassic dolerite dikes in southern Quebec and New England. The absence of rift basins in central New England and Quebec suggests that these regions were characterized by a high topographic elevation induced by a regional thermal event related to the WMMS in Early Jurassic time.

\section{A C K N O W LED GM EN T S}

We sincerely thank J. S. Bell, J. Z. de Boer, and P. $S$. Ross for their comments on earlier versions of the manuscript, as well as P. Jutras, A. Anderson, and an anonymous reviewer for formal reviews. This study was supported by a doctoral fellowship from Fonds Québécois de la Recherche sur la Nature et les Technologies to S. Faure and by a National Sciences and Engineering Research Council of Canada personal grant (PG 105669) to A. Tremblay.

\section{R E F E R E N C E S C I T E D}

Anderson, E. M. 1942. The dynamics of faulting. 1st ed. Edinburgh, Oliver and Boyd, 206 p.

Angelier, J. 1984. Tectonic analysis of fault slip data sets. J. Geophys. Res. 89:5835-5848.

- 1989. From orientation to magnitudes in paleostress determinations using fault slip data. J. Struct. Geol. 11:37-50.

1990. Inversion of field data in fault tectonics to obtain the regional stress. III. A new rapid inversion method by analytical means. Geophys. J. Int. 103:363376.

- 1994. Fault slip analysis and paleostress reconstruction. In Hancock, P. L., ed. Continental deformation. Oxford, Pergamon, p. 53-100.

Angelier, J., and Manoussis, S. 1980. Classification automatique et distinction de phases superposées en tectonique cassante. C. R. Acad. Sci. Paris 290:651-654.

Barnett, R. L.; Arima, M.; Blackwell, J. D.; Winder, C. G.; Palmer, H. C.; and Hayatsu, A. 1984. The Picton and Varty Lake ultramafic dikes: Jurassic magmatism in the St. Lawrence Platform near Belleville, Ontario. Can. J. Earth Sci. 21:1460-1472.

Barosh, P. J. 1986. Neotectonic movement, earthquakes and stress state in the eastern United States. Tectonophysics 132:117-152.

Beck, M. E., and Housen, B. A. 2003. Pre-drift extension of the Atlantic margins of North America and Europe based on paths of Permo-Triassic apparent polar wander. Geophys. J. Int. 152:68-78.

Bédard, J. H. 1992. Jurassic quartz-normative tholeiite dikes from Anticosti Island, Quebec. In Puffer, J. H., and Ragland, P. C., eds. Eastern North American Mesozoic magmatism. Geol. Soc. Am. Spec. Pap. 268: 161-167.

Bertrand, R. 1987. Maturation thermique et potentiel pétroligène des séries post-taconiennes du nord-est de la Gaspésie et de l'Ile d'Anticosti. PhD thesis, Université de Neuchâtel, France. 647 p.

Bott, M. H. P. 1959. The mechanics of oblique slip faulting. Geol. Mag. 96:109-117.

Bourque, P. A.; Brisebois, D.; and Malo, M. 1995. Middle Paleozoic rocks of Quebec and adjacent New Brunswick. In Williams, H., ed. The Appalachian/Caledo- nian Orogen: Canada and Greenland. Geol. Soc. Am. DNAG, vol. F-1, p. 316-351.

Bradley, D. C. 1982. Subsidence in Late Paleozoic basins in the northern Appalachians. Tectonics 1:107-123.

Carey, E., and Brunier, B. 1974. Analyse théorique et numérique d'un modèle mécanique élémentaire appliquée à l'étude d'une population de failles. C. R. Acad. Sci. Paris 279:891-894.

Carignan, J.; Gariépy, C.; and Hillaire-Marcel, C. 1997. Hydrothermal fluids during Mesozoic reactivation of the St. Lawrence rift system, Canada: C, O, Sr and $\mathrm{Pb}$ isotopic characterization. Chem. Geol. 137:1-21.

Charbonneau, J. M. 1980. Région de Sutton. Rep. DPV681. Quebec, Ministère de l'Énergie et des Ressources, $89 \mathrm{p}$.

Clark, T. H. 1972. Montreal area. Geol. Rep. 152. Quebec, Ministère des Richesses Naturelles du Québec, 244 p.

Colpron, M. 1990. Rift and collisional tectonics of the Eastern Townships Humber Zone, Brome Lake area, Quebec. MS thesis, University of Vermont, Burlington.

de Boer, J. Z. 1992. Stress configurations during and following emplacement of ENA basalts in the northern Appalachians. In Puffer, J. H., and Ragland, P. C., eds. Eastern North American Mesozoic magmatism. Geol. Soc. Am. Spec. Pap. 268, p. 361-378.

de Boer, J. Z.; McHone, J. G.; Puffer, J. H.; Ragland, P. C.; and Whittington, D. 1988. Mesozoic and Cenozoic magmatism. In Sheridan, R. E., and Grow, J. A., eds. The Atlantic continental margin: U.S. (Geology of North America, Vol. I-2). Boulder, CO, Geol. Soc. Am., p. 217-241.

Dunn, A. M.; Reynolds, P. H.; Clarke, D. B.; and Ugidos, J. M. 1998. A comparison of the age and the composition of the Shelburne dike, Nova Scotia, and the Messejana dike, Spain. Can. J. Earth Sci. 35:11101115.

Dupin, J. M.; Sassi, W.; and Angelier, J. 1993. Homogeneous stress hypothesis and actual fault slip: a distinct element analysis. J. Struct. Geol. 15:1033-1043.

Emerman, S. F., and Marrett, R. 1990. Why dikes? Geology 18:231-233.

Etchecopar, A.; Vasseur, G.; and Daignières, M. 1981. An 
inverse problem in microtectonics for the determination of stress tensors from faults striation analysis. J. Struct. Geol. 3:51-65.

Faure, S. 1995. Reconstitution des paléocontraintes tectoniques dans les Basses-Terres du Saint-Laurent et les Appalaches du Québec et du nord du NouveauBrunswick. PhD thesis, Université du Québec, INRSGéoressources, 259 p.

Faure, S.; Tremblay, A.; and Angelier, J. 1996a. Alleghanian paleostress reconstruction in the Northern Appalachians: intraplate deformation between Laurentia and Gondwana. Geol. Soc. Am. Bull. 108:14671480.

- $1996 \mathrm{~b}$. State of intraplate and tectonism of northeastern America since Cretaceous time, with particular emphasis on the New England-Quebec igneous province. Tectonophysics 225:111-134.

Faure, S.; Tremblay, A.; and Malo, M. 2004. Reconstruction of Taconian and Acadian paleostress regimes in the Quebec and northern New Brunswick Appalachians. Can. J. Earth Sci. 41:619-634.

Foland, K. A., and Faul, H. 1977. Ages of the White Mountain intrusives: New Hampshire, Vermont, and Maine, USA. Am. J. Sci. 277:888-904.

Foland, K. A.; Gilbert, L. A.; Sebring, C. A.; and JiangFeng, C. $1986 .{ }^{40} \mathrm{Ar} /{ }^{39} \mathrm{Ar}$ ages for plutons of the Monteregian Hills, Quebec: evidence for a single episode of Cretaceous magmatism. Geol. Soc. Am. Bull. 97: 966-974.

Gapais, D.; Cobbold, P. R.; Bourgeois, O.; Rouby, D.; and de Urreiztieta, M. 2000. Tectonic significance of faultslip data. J. Struct. Geol. 22:881-888.

Geological Survey of Canada. 1985a. Disraeli, Quebec. Geol. Surv. Can. Geophys. Ser. (aeromagnetic total field) map C21067G.

.1985b. Scotstown, Quebec. Geol. Surv. Can. Geophys. Ser. (aeromagnetic total field) map C21066G.

Glasmacher, U. A.; López-Martinez, A.; Tremblay, A.; Zentilli, M.; Wagner, G. A.; and Balcázar, M. 2002. Cretaceous and Tertiary tectono-thermal evolution of the Laurentian margin in Quebec, Canada: preliminary results. Geotemas 4:83-89.

Glasmacher, U. A.; Tremblay, A.; and Zentilli, M. 1998. Post-Triassic thermo-tectonic evolution of the Laurentian margin in Quebec, Canada. Geol. Assoc. Can. meeting, Quebec, Abstr. 23:A-66.

Guiraud, M.; Laborde, O.; and Philip, H. 1989. Characterization of various types of deformation and their corresponding deviatoric stress tensors using microfault analysis. Tectonophysics 170:289-316.

Hancock, P. L. 1985. Brittle microtectonics: principles and practice. J. Struct. Geol. 7:437-457.

Hardcastle, K. C. 1989. Possible paleostress tensor configurations derived from fault slip data in eastern Vermont and western New Hampshire. Tectonics 8:265284.

Hardcastle, K. C., and Albaugh, D. S. 1990. Stress and timing relationships of a fault-related, paleohydrothermal system in central New Hampshire: record of a Mesozoic stress change in New England? Tectonics 9:623-639.

Hasegawa, H. S. 1986. Seismotectonics in eastern Canada, an overview with emphasis on the Charlevoix and Miramichi regions. Earthquake Notes 51:23-37.

1991. Four seismogenic environments in eastern Canada. Tectonophysics 186:3-17.

Hatch, N. L., Jr. 1988. New evidence for faulting along the "Monroe Line," eastern Vermont and westernmost New Hampshire. Am. J. Sci. 288:1-18.

Hayman, N. W., and Kidd, W. S. F. 2002. Reactivation of prethrusting, synconvergence normal faults as ramps within the Ordovician Champlain-Taconic thrust system. Geol. Soc. Am. Bull. 114:476-489.

Jutras, P.; Prichonnet, G.; and McCutcheon, S. $2003 a$. Alleghanian deformation in the eastern Gaspé Peninsula of Quebec, Canada. Geol. Soc. Am. Bull. 115: 1538-1551.

- 2003b. Alleghanian faulting in the southern Gaspé Peninsula of Quebec. Atl. Geol. 39:197-207.

Kirkwood, D., and Malo, M. 1993. Across-strike geometry of the Grand Pabos fault zone: evidence for Devonian dextral transpression in the Quebec Appalachians. Can. J. Earth Sci. 30:1363-1373.

Klitgord, K. D.; Hutchinson, D. R.; and Schouten, H. 1988. U.S. Atlantic continental margin: structural and tectonic framework. In Sheridan, R. E., and Grow, J. A., eds. The Atlantic continental margin: U.S. (Geology of North America, Vol. I-2). Boulder, CO, Geol. Soc. Am., p. 19-55.

Klitgord, K. D., and Schouten, H. 1986. Plate kinematics of the central Atlantic. In Vogt, P. R., and Tucholke, B. E., eds. The western North Atlantic region (Geology of North America, Vol. M). Boulder, CO, Geol. Soc. Am., p. 351-378.

Kumarapeli, P. S. 1985. Vestiges of Iapetan rifting in the west of the northern Appalachians. Geosci. Can. 12: 54-59.

Lamontagne, M.; Keating, P.; and Perreault, S. 2003. Seismotectonic characteristics of the Lower St. Lawrence Seismic Zone, Quebec: insights from geology, magnetics, gravity, and seismics. Can. J. Earth Sci. 40:317336.

Lee, J. C.; and Angelier, J. 1994. Paleostress trajectory maps based on the results of local determinations: the "Lissage" program. Comput. Geosci. 20:161-191.

Lemieux, Y.; Tremblay, A.; and Lavoie, D. 2003. Structural analysis of supracrustal faults in the Charlevoix area, Quebec: relation to impact cratering and the StLaurent fault system. Can. J. Earth Sci. 40:221-235.

Le Pichon, X.; Sibuet, J. C.; and Francheteau, J. 1977. The fit of the continents around the North Atlantic Ocean. Tectonophysics 38:169-209.

Malo, M., and Bourque, P. A. 1993. Timing of the deformation events from Late Ordovician to mid-Devonian in the Gaspé Peninsula. In Roy, D. C., and Skehan, J. W., eds. The Acadian Orogeny: recent studies in New England, maritime Canada, and the autochthonous foreland. Geol. Soc. Am. Spec. Pap. 275, p. 101-122. Manspeizer, W., and Cousminer, H. L. 1988. Late 
Triassic-Early Jurassic synrift basins of the U.S. Atlantic margin. In Sheridan, R. E., and Grow, J. A., eds. The Atlantic continental margin: U.S. (Geology of North America, Vol. I-2). Boulder, CO, Geol. Soc. Am., p. 197-216.

Manspeizer, W.; de Boer, J.; Costain, J. K.; Froelich, A. J.; Coruh, C.; Olsen, P. E.; McHone, G. J.; Puffer, J. H.; and Prowell, D. C. 1989. Post-Paleozoic activity. In Hatcher, R. D., Jr.; Thomas, W. A.; and Viele, G. W., eds. The Appalachian-Ouachita Orogen in the United States (Geology of North America, Vol. F-2). Boulder, CO, Geol. Soc. Am., p. 319-374.

McHone, J. G. 1978. Distribution, orientations and ages of mafic dikes in central New England. Geol. Soc. Am. Bull. 89:1645-1665.

1984. Mesozoic igneous rocks of northern New England and adjacent Quebec: summary, description of map, and bibliography of data sources. Geol. Soc. Am. map and charts series MC-49, 5 p.

1988. Tectonic and paleostress patterns of Mesozoic intrusions in eastern North America. In Manspeizer, W., ed. Triassic-Jurassic rifting, continental breakup and the origin of the Atlantic Ocean and passive margins. Developments in Geotectonics. Vol. 22. Amsterdam, Elsevier, p. 607-620.

McHone, J. G., and Butler, J. R. 1984. Mesozoic igneous provinces of New England and the opening of the North Atlantic Ocean. Geol. Soc. Am. Bull. 95:757765.

McHone, J. G.; Ross, M. E.; and Greenough, J. D. 1987. Mesozoic dikes swarms of eastern North America. In Halls, H. C., and Fahrig, W. F., eds. Mafic dike swarms. Geol. Assoc. Can. Spec. Pap. 34, p. 279-288.

McHone, J. G., and Shake, S. N. 1992. Structural control of Mesozoic magmatism in New England. In Mason, R., ed. Basement tectonics. Vol. 7. Dordrecht, Kluwer, p. 399-407.

McMaster, R. L.; de Boer, J.; and Collins, B. P. 1980. Tectonic development of southern Narragansett Bay and offshore Rhode Island. Geology 8:496-500.

Oliver, J.; Johnson, T.; and Dorman, J. 1970. Postglacial faulting and seismicity in New York and Quebec. Can. J. Earth Sci. 7:579-590.

Pe-Piper, G.; Jansa, L. F.; and St. Lambert, R., Jr. 1992. Early Mesozoic magmatism on the eastern Canadian margin: petrogenetic and tectonic significance. In Puffer, J. H., and Ragland, P. C., eds. Eastern North American Mesozoic magmatism. Geol. Soc. Am. Spec. Pap. 268, p. 13-36.

Pe-Piper, G., and Reynolds, P. H. 2000. Early Mesozoic alkaline mafic dikes, southwestern Nova Scotia, Canada, and their bearing on Triassic-Jurassic magmatism. Can. Mineral. 38:217-232.

Petit, J. P. 1987. Criteria for the sense of movement on fault surfaces in brittle rocks. J. Struct. Geol. 9:597608.

Petryk, A. A. 1981. Carte géologique de l'Ile d'Anticosti. Rep. DPV-823. Québec, Ministère de l'Énergie et des Ressources, $14 \mathrm{p}$.

Pollard, D. D. 1987. Elementary fracture mechanics ap- plied to the structural interpretation of dikes. In Halls, H. C., and Fahrig, W. F., eds. Mafic dike swarms. Geol. Assoc. Can. Spec. Pap. 34, p. 5-24.

Rocher, M., and Tremblay, A. 2001. L'effondrement de la plate-forme du Saint-Laurent: ouverture de Iapetus ou de l'Atlantique? apport de la reconstitution des paléocontraintes dans la région de Québec (Canada). C. R. Acad. Sci. Paris 333:171-178.

Rocher, M.; Tremblay, A.; Lavoie, D.; and Campeau, A. 2003. Brittle evolution of the Montreal area (St. Lawrence Lowlands, Canada): rift-related structural inheritance and tectonism approached by paleostress analysis. Geol. Mag. 140:157-172.

Roddick, J. C.; Quigg, F. B.; and Hunt, P. A. 1992. Miscellaneous ${ }^{40} \mathrm{Ar}-{ }^{39} \mathrm{Ar}$ ages and analytical procedures. Geol. Surv. Can. Radiogen. Age Isot. Stud. Rep. 6, Pap. 92-2, p. 171-177.

Rondot, J. 1968. Nouvel impact météoritique fossile? la structure semi-circulaire de Charlevoix. Can. J. Earth Sci. 5:1305-1317.

—. 1989. Géologie de Charlevoix. Rep. MB 89-21. Quebec, Ministère de l'Énergie et des Ressources, 606 p.

Schlische, R. W. 1993. Anatomy and evolution of the Triassic-Jurassic continental rift system, eastern North America. Tectonics 12:1026-1042.

- 2003. Progress in understanding the structural geology, basin evolution, and tectonic history of the eastern North American rift system. In LeTourneau, P. M., and Olsen, P. E, eds. The great rift valleys of Pangea in eastern North America. Vol. 1. Tectonics, structure, and volcanism. New York, Colombia University Press, p. 21-64.

Séjourné, S.; Dietrich, J.; and Malo, M. 2003. Seismic characterization of the structural front of southern Quebec Appalachians. Bull. Can. Petrol. Geol. 51:2944.

Spencer, C.; Green, A.; Morel-à-l'Huissier, P.; Milkereit, B.; Luetgert, J.; Stewart, D.; Unger, J.; and Phillips, J. 1989. The extension of Grenville basement beneath the northern Appalachians: results from the QuebecMaine seismic reflection and refraction surveys. Tectonics 8:677-696.

St-Julien, P., and Hubert, C. 1975. Evolution of the Taconian Orogen in the Quebec Appalachians. Am. J. Sci. 275-A:337-362.

St-Julien, P.; Slivitsky, A.; and Feininger, T. 1983. A deep structural profile across the Appalachians of southern Quebec. In Hatcher, R. D., Jr.; Williams, H.; and Zietz, I., eds. Contributions to the tectonics and geophysics of mountain chains. Geol. Soc. Am. Mem.158, p. 103111.

Stockmal, G. S.; Colman-Sadd, S. P.; Keen, C. E.; O’Brien, S. J.; and Quinlan, G. M. 1987. Collision along an irregular margin: a regional plate tectonic interpretation of the Canadian Appalachians. Can. J. Earth Sci. 24:1098-1107.

Swanson, M. T. 1986. Preexisting fault control for Mesozoic basin formation in eastern North America. Geology 14:419-422. 
Thomas, W. A. 1977. Evolution of Appalachian-Ouachita salients and recesses from reentrants and promontories in the continental margin. Am. J. Sci. 277:12331278.

Tremblay, A.; Long, B.; and Massé, M. 2003. Supracrustal faults of the St. Laurence rift system, Quebec: kinematics and geometry as revealed by field mapping and marine seismic reflection data. Tectonophysics 369: 231-252.

Wallace, R. E. 1951. Geometry of shearing stress and relation to faulting. J. Geol. 59:118-130.

Wanless, R. K., and Stevens, R. D. 1971. Note on the age of diabase dikes, Anticosti Island, Quebec. Geol. Assoc. Can. Proc. 23:77-78.

Williams, H. 1979. Appalachian Orogen in Canada. Can. J. Earth Sci. 16:792-807.

Williams, H., and Hatcher, R. D., Jr. 1983. Appalachians suspect terranes. In Hatcher, R. D., Jr.; Williams, H.; and Zietz, I., eds. Contributions to the tectonics and geophysics of mountain chains. Geol. Soc. Am. Mem. 158 , p. 33-53.

Wise, D. U. 1988. Mesozoic stress history of the upper Connecticut Valley at Turners Falls, Massachusetts. In New England Intercollegiate Geological Conference, 74th annual meeting (Keene, NH). Fieldtrip guidebook, p. 351-372.

Withjack, M. O.; Schlische, R. W.; and Olsen, P. E. 1998. Diachronous rifting, drifting, and inversion on the passive margin of central eastern North America: an analog for other passive margins. Am. Assoc. Pet. Geol. Bull. 82:817-835.

Yamaji, A. 2003. Are the solutions of stress inversion correct? visualization of their reliability and the separation of stresses from heterogeneous fault-slip data. J. Struct. Geol. 25:241-252. 